\title{
Review of Civilian Experience in Conflict Situation
}

\author{
Aliyu Yero ${ }^{1}$, Jamilah Othman ${ }^{2}$, Ahmad Talib ${ }^{3}$, Shamsuddin B. Ahmad ${ }^{4} \&$ Jeffrey Lawrence D’Silva $^{2}$ \\ ${ }^{1}$ Department of Political Science, Kaduna State University, Nigeria \\ ${ }^{2}$ Laboratory for Citizenship \& Leadership, Institute for Social Science Studies, Universiti Putra Malaysia, \\ Malaysia \\ ${ }^{3}$ Department of Government and Civilization Studies, Universiti Putra Malaysia, Malaysia \\ ${ }^{4}$ Department of Professional Development and continuing Education, Universiti Putra Malaysia, Malaysia \\ Correspondence: Jeffrey Lawrence D’Silva, Laboratory for Citizenship \& Leadership, Institute for Social \\ Science Studies, Universiti Putra Malaysia, Malaysia. E-mail: jld@putra.upm.edu.my
}

Received: November 13, 2013 Accepted: December 12, 2013 Online Published: January 26, 2014

doi:10.5539/ass.v10n4p139

URL: http://dx.doi.org/10.5539/ass.v10n4p139

\begin{abstract}
There is a growing concern among scholars on how the battlefield of conflict/wars have shifted to civilian populated areas causing huge pain and loss, previous studies have shown that civilians today have become entangled in a precarious situation where conflicts rage forcing them to either take charge of their fate or risk living in continuous fear of being used as scape-goats by either of the parties in conflict. This paper strife's to bring to fore some of the challenges faced by civilians in conflict. Also, by reflecting on previous studies, room will be created for a prompt analysis of what civilians go through in the event of an impending conflict. Using existent literature, previous studies and reports from international organizations and actors in the field of conflict management, the paper highlight the nature, impact and experiences related to conflict and how these processes undermine the realization of basic human needs for survival among civilians. Borrowing from the Human Needs theory, the paper concludes that the realization of human potentials will not be attainable unless the need for security and safety is guaranteed. Failure to protect civilians in need of protection will ultimately put the faith of the people in their hands and thus promote the proliferation of light arms which has the potential for misuse and further endangering the civilian population.
\end{abstract}

Keywords: conflict, war, civilians, victimization, experience

\section{Introduction}

Throughout human history, conflict has remained persistent at all levels of human experience. Nevertheless, not in all instances where conflict exist that violence exist, some conflicts are violent and some are not. Human experience to conflict can also been perceived from various facets depending on group characteristics. The experience of women may differ from the experience of children, while also the experience of combat men and non-combat men may also differ. Nevertheless, experience of conflict either violent or non-violent happens to be an undesirable phenomenon while experience of peace whether positive or negative also has a comforting constituent which is desirable. Throughout wars and conflict situations, there appears to be trend through which civilians have carried some of the worst burdens.

Globally, there has been a sharp decrease in international conflicts since the end of the Cold War. Nonetheless, there exists a sharp increase in intra-national (civil) conflicts. Following the collapse of the Soviet empire; this trajectory peaked in 1991, with a $40 \%$ decrease in the number of civil wars by 2003 (Binningsbø, Elster, \& Gates, 2005). It is the interest of this paper to look at some of the studies on civilian experience with a view to highlight the prominent occurrences. Also, through their experience we can be able to learn what people go through in situations of war which can serve as a guide towards the quest for peace and the exact needs in times of intervention.

\section{Nature of Conflict}

The conflict literature is mountainous and so extensive (Wall \& Callister, 1995). It is intricate to define conflict as it is challenging to derive a consensus on the definition of this term (Jordan \& Troth, 2004). This is because conflict has been with us for a long time and since then, scholars have been writing about it. 
Scholars are of the opinion that defining conflict will be a herculean task considering the different attitudes displayed by people. The term conflict originated from Latin signifying "to clash or engage in a fight" portraying hostility between one or more parties aspiring who are clamoring for incompatible or competitive means or ends (Miller \& King, 2005). (Gleditsch, Wallensteen, Eriksson, Sollenberg, \& Strand, 2002) identified three general forms associated to conflict: the first is the inter-state followed by internal and lastly state-formation conflict, in a survey by Hocker and Wilmot in Plowman (1998) tries to understand how people perceive the concept of conflict indicate that respondents identified concepts like "destruction", "anger", "disagreement", "hostility", "war", "anxiety", "tension", "alienation", "violence", "competition", "threat", "heartache", "pain" and "hopelessness". This clearly shows that people view conflict as a negative phenomenon on a general note.

The view that conflict is only negative have remain for a long time even among scholars (Simons, 1972), for example, Hocker and Wilmot highlighted some negative suppositions regarding conflict which appears popular, one of such assumptions is that harmony is normal while conflict is abnormal, furthermore conflict and disagreement was aligned to be similar. Also, conflict is like a syndrome that must be removed. In effect therefore, conflict represents a collision that must be avoided.

As the notion of conflict being negative dominates, some scholars came to challenge the assumption Deetz and Stevenson (1986) proposed three prepositions which assumes that conflict could be positive; firstly, conflict is a natural phenomenon. Secondly, conflict is unavoidable and thirdly, conflict is a product of genuine differences. As a natural phenomenon, conflict is unavoidably an aspect of human experience.

On a general note, Robbins (2005) observed that conflict has been perceived by scholars in three broad categories: the traditionalist view, human relationist view and interactionist.

\subsection{The Traditional View (1930-1940)}

This perspective perceives conflict from a masculine angle and also an experience that man must avoid at all cost. This negative view of relates conflict to direct violence and destruction resulting from skewed communication as well as inability to trust.

\subsection{The Human Relations View (1940-1970)}

This school associates conflict to be a group affair which is natural and can positively enhance the performance of groups. Leung (2010) believe that conflict cannot be avoided and thus no need to exert effort to avoid it or deter it.

\subsection{The Interactionist View (Post 1970'S)}

This school of thought advance the debate on conflict believing that the end result will inevitably lead to change and creativity. Conflict pushed groups to function better. Nevertheless conflict for interactionist can also be negative. Three broad categories have been identified which are; task conflict: relating to composition and objectives at work, relationship conflict: associated with interpersonal affairs and process conflict: which refers to the manner tsk gets delivered (Robbins, 2005).

\section{Impact of Conflicts}

The impact of conflict/war trauma is a significant global issue (Pedersen, 2002). The immediate and direct impact of conflict/war is well-established in the literature and includes battle deaths, ethnic cleansing, gender-based violence, torture and displacement (Pedersen, 2002; Summerfield \& Toser, 1991). Researchers estimate that over 231 million people died in wars and conflict in the twentieth century (Leitenberg, 2006). Since World War II, civilian deaths have far exceeded combat-related deaths (Pedersen, 2002; Leitenberg, 2006), yet most researches have focused on traumatic events arising from direct combat and its symptoms (Bliese, Wright, Adler, Cabrera, Castro, \& Hoge, 2008; Boscarino, 2004; Eisenbruch, de Jong, \& van de Put, 2004; Wang, Wilson, \& Mason, 1996). Pedersen (2002) has argued that civilian deaths have increased as a result of wars of terror that target the local populations, politicize civilians to garner their loyalty, and destroy those who don't support the rebels'. Scholars have focused on the most vulnerable victims of such atrocities like children/adolesents (Boyden, 1994; Giacaman, Shannon, Saab, Arya, \& Boyce, 2007), Youth (Barber, 2013).

\section{Nature of Experience}

Literally, experience as a phenomenon involves being engaged or acquaintance to things or events (OED, 1989). When discussing on issues related to experience in human, it depends on the context one is grounding his approach; is it through the individual perceiving or the thing being perceived. This paper primarily focuses on victims perceived experiences in relation to conflict situations with a view to assess the salient issues surrounding the topic. 
Experience represents an umbrella concept involving multiple facets all attempting to explain actual observation of facts or events which is considered a source of knowledge within individuals. Often, people who have found themselves in conflict situations have found life to be extremely difficult to live an can only be understood from their own tales, not many people will attempt to get in to conflict zones and it becomes difficult for people outside to know how it actually feels to live in a conflicting society. Experience can also be studies during a particular period of time or generally about the life of an individual.

Because people are different inherently, it is obvious that two people can have different experiences when perceiving the same phenomenon. Experience can also vary on location; i.e. the victim's experience of conflict in Africa could be different from victim's experience of conflict in Asia. Essentially, experience can be subdivided into many categories such as physical experience, mental experience, emotional experience, spiritual experience, religious experience, social experience or subjective experience. In fact, all aspects of existence possess experiential qualities which could be attained and in this paper we are concerned about conflict experience as a product of social experience arising from human interaction.

\section{Civilian Victims Experience in Conflict}

The summation of civilian victims of war and conflict represents a culmination of astonishing emotional and physical toll. In this regard, several international agencies have produced on the spot assessment reports through studies conducted in conjunction with research bodies on the civilian victims and their experiences in conflict situations from different parts of the world. Examples of such expression can be found in Oxfam assessment in titled "commodities of war: communities speak out on the true cost of conflict in eastern Congo" (Van Damme, 2012). Oxfam observed that there exist:

"... alarming levels of abuse of men, women and children by armed groups, including through forced recruitment, forced labour and continuous illegal taxation in one of the world's most under-reported and appalling human rights crises. In areas subject to attack by armed groups, people expressed fears about killings, looting and abductions. In areas largely controlled by the state, people reported exploitation, including extortion under threat of violence, by the very state officials who are supposed to protect and support them" (Van Damme, 2012, p. 2).

This scenario depicts a horrific experience as the line between civilian and combat soldiers has become blurred. Civilians have become entangled in a circle of violence which they are not party with no one to protect them but rather they are exploited, their faith is put back in their hands and it has become their sole business to stay alive, self-defense in this case has become the last resort for them, it is determining factor between life and death. This was rightly depicted in Oxfam's assessment as observed:

"In several areas such as northern Masisi, the small market town of Kashuga, people felt compelled to take security and justice into their own hands due to an abusive or absent state, adding to the growing numbers of new armed groups... People feel abandoned and increasingly frustrated by those whose duty it is to protect them" (Van Damme, 2012, pp. 2-3).

Oxfam's assessment conclude that "men and women still experience insecurity in different ways, while traditional ways of coping with challenges are under increasing strain" (2012, p. 3).

Another vital document that exhibits the bitter the experience face by civilians in times of conflict is the "People on War report" 1999 prepared by the Greenberg research Inc. The report observed that by the end of the $20^{\text {th }}$ century, the arena of war can best be described as a scenario where civilian form the nucleus, this is a departure from what was obtainable in the past where wars are fought in the battlefields. Gutman and Rieff (1999) eloquently described the vital conversion of the manner in which war is conducted by illustrating a striking statistics which compared the ratio civilian casualties to army combatants death; in world war one, it is projected that 9 soldiers were killed for every civilian loss. In today's war, it is projected that 10 civilians die for every soldier or combatant killed.

It is worrying to see the growth of a culture of war which has placed civilians at the centre of the conflict. The People on war report described the consequences of civilian experiences as constituting extraordinary emotional and physical cost. Results from survey carried out in 12 countries that have endured modern form of war, with respondent's population ranging from 1,000 to 1,500 in each of the 12 countries. The report depicts that across all the war-torn settings surveyed, people say that the conflict for them was, above all, "horrible" (49 per cent). This dominant intense description was used most often in Abkhazia (61 per cent), Bosnia-Herzegovina (72 per cent) and Somalia (61 per cent). After "horrible", people described the conflict as "hateful" (30 per cent), "disruptive" (26 per cent) and "humiliating" ( 24 per cent). Furthermore, the most common experience among 
civilians is the radical disruption of family life where more than $40 \%$ respondents say they lost contact with a close relative, more than half the people lost touch with family while more than one third was forced to leave their homes. In Somalia for example, almost two third were dislocated (63\%), and in Afghanistan, almost everyone was dislocated (83\%). Overall, $31 \%$ reported that somebody in their immediate family died in war.

In as much as war/conflict occur, civilians will continue to be pushed to participate or take side even against their will, it remains a puzzling issue today on how or to what extent can civilians be protected from being victimized? To what extent can those saddled with the responsible of protecting civilians be held responsible? Is it possible to completely shield civilians from being victimized? These and many other questions remain unanswered.

\section{Theoretical Framework}

\subsection{Human Needs Theory}

As human beings interact and relate with each other, divergent views emerge bordering on issues related to all aspect of existence, which inevitably leads to conflict. According to human needs theorist (HNT), in order for human beings to ascertain well-being, certain basic needs must be met (Danielsen, 2005). Rosenberg (2003) was of the opinion that whenever there is violence, it is an indication that certain basic needs of people are unattainable; this represents a majority of human needs theorist. Several scholars (Maslow, Burton, Rosenberg, $\&$ Max-Neef), have used human needs theory to depict the hierarchical need of noting that some are more prime than others (Danielsen, 2005).

Within Maslow's hierarchy some needs are prime than others which is being depicted using the pyramid scale, Maslow puts water, food and shelter on the top. This is followed by the need for safety and security, thirdly Maslow identified belonging or love and fourthly, self-esteem. Personal fulfilment made it at the bottom of the needs hierarchy. John Burton on the other hand utilized human needs theory to explain social and political conflict; his work focus on how groups are pushed to conflict due to the disregard for human needs which are globalized. However, Marshall Rosenberg in his contributions to human needs theory hinges on the idea that the basic needs which are universal have sub-groups and not guaranteeing these needs will threaten the survival of human well-being.

In another view, Manfred Max-Neef introduced human scale development which is primarily on the satisfaction of nine fundamental human needs. Max-Neef was of the opinion that no need is superior than another and Burton and Rosenberg concord with him, only Maslow was of the opinion that needs must be ranked and that some are more important than some. For the purpose of this paper, the human needs theory is used to bring to perspective how conflicts/war undermines the realization of human basic needs such as water, food and shelter which appears at the top list of Maslow's analysis, as well as safety and security. The loss of these basic needs appear common in most conflict situations and pose great threat to civilians, the experience of losing the most basic of human needs puts civilians in a highly vulnerable situation which cannot be quantified.

In the same vain, despite losing the most basic of human needs, civilians are consistently threatened by the absence of security and safety characterized by confusion and fear. The scenario is that the battle ground for conflicts and wars have shifted to the door steps of civilians, this shift has taken away a vital need which is security and civilians are in the middle of the battlefield. This means that, the combatant line cannot be precisely drawn; civilians have been brought into the scene as shields thus being most vulnerable of the parties in conflict/war.

Since the human needs theorist are of the opinion that the absence or lack of access to these basic needs have the potential of pushing people into conflict, in this paper the analogy is that the absence of civilian basic needs have pushed people to either turn in as combatants in an attempt to protect themselves. This amount to a situation whereby the civilian population is militarized (Militarization of the civilians). It basic point here is that the only means through which civilians can cope with their experiences is to take up arms and protect themselves, providing their own security and safety by themselves as a basic need. The impact of militarization of civilians further deepens the conflict situation in many ways; one of such ways is a situation where light weapons flow into the hands of civilians. The danger of light weapon proliferation among civilians has the potential of been misused (Herby, 1999), this scenario according to Meddings (2001), has brought serious concern to international community, the crux of the matter is how to control the flow of light weapon into the hands of civilians?

\section{Recommendations and Conclusion}

The horrible condition civilians in conflict situation are entangled in can no more be tolerated, the consequences possess both short and long term impurity that last a life time. The world today is gradually falling short of managing the outcome of conflict and its impact on civilians with resources at limited supply. Scholars appear 
uncertain as to what best ways civilians could be protected from conflicts they are not party to. Philosophical reflections of Mao Zedong, Machiavelli and Sun Tzu may be invoked, "The best defense is a good offense". Therefore, for civilians to ensure their protection in conflicts situations they have to prepare to lunch an offence. As noble as this philosophy is, it fall short of protecting the weak such as the old, women and children who cannot defend themselves but rather have to be defended. Furthermore, the element of neutrality maintained by civilians will be lost completely; civilians will eventually turn out to be parties as well. However, one could argue that the element of neutrality itself did not protect the civilians as well. Nevertheless, this paper is of the opinion that more is expected from civilians rather than just migrating, perhaps a little push towards self-defense at community level could offer a relief.

The idea of community level self-defense mechanism does not exonerate conflicting parties from avoiding civilian causalities, nor does it vindicate the international organizations at regional and global level from stepping up modalities for civilian protection in armed conflict situation, in fact, more is expected in terms of stiffer punishment to any group or groups of parties in conflict situation where civilians suffer untold hardship. The instrument of the international court of justice must be stronger and more effective; the scenario where some countries are signatories and some are not is discouraging. More effort is also needed in prevention rather than cure as it is cheaper.

It is a living reality of today's world that civilians have been drawn from their homes to the battlefield as active participants. This bitter reality have glaringly taken some of the basic needs of people for their, in fact the destiny of civilian populations in conflict situations have been put in the hands. Active actors in conflict have consistently amassed huge civilian casualties all in the name of "collateral damage", one wonders whether war/conflicts have any ethics? It is hard to imagine in a conflict situation that any ethic can be observed especially as the society has become the battle ground. Looking at assessments of scholars and reports from international bodies, it is clear that urgent measure need to be taken to emancipate the civilians from the shackles of violence they have found themselves which in the end they have very little to do with either the remote or immediate causes. There appears to be a growing weakening of the modern state in a time of growing intra-national conflicts and raising terrorism, if the state is no longer in a position to guarantee the protection of civilian lives and properties who or which institution then is in a position to carry out that function? This question if answered could offer a glimpse of hope and if not answered, then a bleak future awaits millions of civilians caught up in violent conflicting societies.

\section{References}

Barber, B. K. (2013). Annual Research Review: The experience of youth with political conflict challenging notions of resilience and encouraging research refinement. Journal of Child Psychology and Psychiatry. http://dx.doi.org/10.1111/jcpp.12056

Binningsbø, H. M., Elster, J., \& Gates, S. (2005). Civil War and Transitional Justice, 1946-2003: A Dataset. Paper presented at the Transitional Justice and Civil War Settlements' workshop in Bogotá, Colombia.

Bliese, P. D., Wright, K. M., Adler, A. B., Cabrera, O., Castro, C. A., \& Hoge, C. W. (2008). Validating the primary care posttraumatic stress disorder screen and the posttraumatic stress disorder checklist with soldiers returning from combat. Journal of consulting and clinical psychology, 76(2), 272. http://dx.doi.org/10.1037/0022-006X.76.2.272

Boscarino, J. A. (2004). Posttraumatic stress disorder and physical illness: Results from clinical and epidemiologic studies. Annals of the New York Academy of Sciences, 1032(1), 141-153. http://dx.doi.org/10.1196/annals.1314.011

Boyden, J. (1994). Children's experience of conflict related emergencies: Some implications for relief policy and practice. Disasters, 18(3), 254-267. http://dx.doi.org/10.1111/j.1467-7717.1994.tb00311.x

Danielsen, G. (2005). Meeting human needs, preventing violence: Applying human needs theory to the conflict in Sri Lanka, Universidad del Salvador Buenos Aires, USAL.

Deetz, S., \& Stevenson, S. L. (1986). Managing interpersonal communication: Harper \& Row. San Francisco.

Eisenbruch, M., de Jong, J. T., \& van de Put, W. (2004). Bringing order out of chaos: A culturally competent approach to managing the problems of refugees and victims of organized violence. Journal of Traumatic Stress, 17(2), 123-131. http://dx.doi.org/10.1023/B:JOTS.0000022618.65406.e8

Giacaman, R., Shannon, H. S., Saab, H., Arya, N., \& Boyce, W. (2007). Individual and collective exposure to political violence: Palestinian adolescents coping with conflict. The European Journal of Public Health, 
17(4), 361-368. http://dx.doi.org/10.1093/eurpub/ck1260

Gleditsch, N. P., Wallensteen, P., Eriksson, M., Sollenberg, M., \& Strand, H. (2002). Armed conflict 1946-2001: A new dataset. Journal of peace research, 39(5), 615-637. http://dx.doi.org/10.1177/0022343302039005007

Gutman, R., \& Rieff, D. (1999). Crimes of war: What the public should know: WW Norton \& Company.

Herby, P. (1999). Arms availability and the situation of civilians in armed conflict: A study presented by the ICRC (International Red Cross). International Red Cross.

Hocker, J. L., \& Wilmot, W. W. (1985). Inter-personal conflict. Dubuque, Iowa: Wm. C. Brown Publishers.

Jordan, P. J., \& Troth, A. C. (2004). Managing emotions during team problem solving: Emotional intelligence $\begin{array}{llll}\text { and } & \text { conflict } \text { resolution. 195an } 218 .\end{array}$ http://dx.doi.org/10.1207/s15327043hup1702_4

Leitenberg, M. (2006). Deaths in Wars and Conflicts in the 20th Century: Cornell University, Peace Studies Program Ithaca, NY.

Leung, Y. F. (2010). Conflict management and emotional intelligence', DBA thesis, Southern Cross University, Lismore, NSW.

Miller, C. A., \& King, M. E. (2005). A glossary of terms and concepts in peace and conflict studies: University for Peace.

Pedersen, D. (2002). Political violence, ethnic conflict, and contemporary wars: Broad implications for health

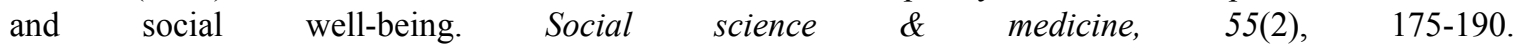
http://dx.doi.org/10.1016/S0277-9536(01)00261-1

Plowman, K. D. (1998). Power in conflict for public relations. Journal of Public Relations Research, 10(4), 237-261. http://dx.doi.org/10.1207/s1532754xjprr1004_02

Robbins, S. P. (2005). Organizational behaviour, Eleventh Edition (Electronic ed.) (pp. 423-431). Published by Prentice-Hall.

Rosenberg, M. B. (2003). Nonviolent communication: A language of life: Create your life, your relationships, and your world in harmony with your values. PuddleDancer Press.

Simons, H. (n. d.). Persuasion in social conflicts: A critique of prevailing concept ions and a framework for future research. Sweech Monosrawhs, 39(1972), 227-247.

Summerfield, D., \& Toser, L. (1991). 'Low intensity' war and mental trauma in Nicaragua: A study in a rural community. Medicine, Conflict and Survival, 7(2), 84-99.

The Oxford English Dictionary. (n. d., Vol. 2). Oxford: Clarendon Press, 1989.

The people on war report. (2000). ICRC worldwide consultation on the rules of war. Greenberg research Inc.

Van Damme, S. (2012). Commodities of war: Communities speak out on the true cost of conflict in eastern DRC. Oxfam GB, Cowley oxford.

Wall, J. A., \& Callister, R. R. (1995). Conflict and its management. Journal of management, 21(3), 515-558. http://dx.doi.org/10.1177/014920639502100306

Wang, S., Wilson, J. P., \& Mason, J. W. (1996). Stages of decompensation in combat-related posttraumatic stress disorder: a new conceptual model. Integrative physiological and behavioural science, 31(3), 237-253. http://dx.doi.org/10.1007/BF02691455

\section{Copyrights}

Copyright for this article is retained by the author(s), with first publication rights granted to the journal.

This is an open-access article distributed under the terms and conditions of the Creative Commons Attribution license (http://creativecommons.org/licenses/by/3.0/). 